\title{
PROBLEM ODMOWY UDZIELENIA ŚWIADCZENIA ZDROWOTNEGO W PODMIOCIE LECZNICZYM
}

\author{
THE PROBLEM OF REFUSAL OF HEALTH SERVICES IN THE HEALTHCARE ENTITY
}

\section{Joanna Zdanowska}

Zakład Organizacji i Zarządzania w Opiece Zdrowotnej,

Uniwersytet Medyczny im. Karola Marcinkowskiego w Poznaniu

DOI: https://doi.org/10.20883/pielpol.2017.38

\section{STRESZCZENIE}

Ustawodawstwo polskie gwarantuje pacjentom prawo do uzyskiwania odpowiednich świadczeń zdrowotnych. Jednak w praktyce nie zawsze jest to możliwe. Lekarz może bowiem odmówić ich udzielenia, jeśli świadczenia te są niezgodne z jego sumieniem. Do niedawna powinien w takim przypadku wskazać pacjentowi realne możliwości uzyskania tego świadczenia u innego lekarza lub w podmiocie leczniczym. Jednakże na mocy wyroku Trybunału Konstytucyjnego z dnia 7 października 2015 r. powyższy zapis został uznany za niekonstytucyjny, co spowodowało konieczność zmiany przepisów w tym zakresie. Podobnie Trybunał orzekł w kwestii obowiązku wykonania przez lekarza świadczenia zdrowotnego niezgodnego z jego sumieniem w tzw. „,innych przypadkach niecierpiących zwłoki".

Celem niniejszej pracy była analiza przepisów prawa stanowiących podstawę odmowy udzielenia świadczenia zdrowotnego przez lekarza oraz wiążących się z tą decyzją obowiązków. Jako wniosek należy wskazać na konieczność takiej zmiany przepisów prawa, która w sytuacji odmowy wykonania świadczenia zdrowotnego przez lekarza zagwarantuje pacjentowi dostęp do informacji o możliwości uzyskania tego świadczenia w innej placówce ochrony zdrowia.

SŁOWA KLUCZOWE: świadczenie zdrowotne, klauzula sumienia, prawo.

\section{Wstęp}

Zdrowie jest jednym z podstawowych dóbr człowieka. Jego ochronę gwarantują zarówno akty prawa międzynarodowego, jak i krajowego. Już w art. 55 Karty Narodów Zjednoczonych podpisanej dnia 26 czerwca $1945 \mathrm{r}$. w celu tworzenia warunków stałości i dobrobytu narody zobowiązały się do podejmowania działań mających na celu rozwiązywanie zagadnień zdrowotnych [1]. Nadto Powszechna Deklaracja Praw Człowieka uchwalona dnia 10 grudnia 1948 r. w art. 25 ust. 1 wśród dóbr służących realizacji prawa „każdego” do życia zapewniającego dobrobyt jemu i jego rodzinie wymienia opiekę lekarską i niezbędne świadczenia socjalne [2]. Szerszą regulację zamieszczono w art. 12 Międzynarodowego

\begin{abstract}
Polish legislation guarantees patients the right to receive adequate health services. However, in practice it is not always possible. The doctor may in fact refuse providing the service if it is not in accordance with his/her conscience. Until recently, he would be required to indicate to the patient the real possibility of obtaining the benefit from another physician or healthcare entity. However, under the Constitutional Tribunal Judgment of 7 October 2015, the above-mentioned provision was declared unconstitutional, which resulted in the need to change legislation in this regard. Similarly, the Tribunal has ruled on the obligation to provide medical health service not in accordance with doctor's conscience in so-called "other urgent cases."

The intention of the authors of this study was to analyze law underlying the refusal of health services by a physician, and associated with this decision duties.

The request is: the need to change legislation and assuring patients of having access to information about obtaining health services in another facility.
\end{abstract}

KEYWORDS: health benefits, conscience clause, law.

Paktu Praw Ekonomicznych, Socjalnych i Kulturalnych z dnia 19 grudnia 1966 r., który gwarantuje każdemu „prawo do korzystania z najwyższego osiągalnego poziomu ochrony zdrowia fizycznego i psychicznego". W celu pełnego wykonania tego prawa państwa strony paktu zobowiązały się podjąć działania konieczne do zapewnienia zmniejszenia wskaźnika martwych urodzeń i śmiertelności niemowląt oraz do zapewnienia zdrowego rozwoju dziecka, poprawy higieny środowiska i higieny przemysłowej we wszystkich aspektach, zapobiegania chorobom epidemicznym, endemicznym, zawodowym i innym oraz ich leczenia i zwalczania, a także stworzenia warunków, które zapewnią wszystkim pomoc i opiekę lekarską na wypadek choroby [3]. 
Podobny zapis znalazł się też w Preambule Konstytucji Światowej Organizacji Zdrowia z dnia 22 lipca 1946 r., w której uznano, że korzystanie z najwyższego osiągalnego poziomu zdrowia jest jednym z podstawowych praw każdej istoty ludzkiej [4].

W ustawodawstwie polskim prawo do ochrony zdrowia gwarantuje art. 68 ust. 1 i 2 Konstytucji RP, który jednocześnie nakłada na władze publiczne obowiązek zapewnienia równego dostępu do świadczeń opieki zdrowotnej finansowanych ze środków publicznych [5]. Dostęp ten nie może być uwarunkowany sytuacją materialną obywatela. Nadto Konstytucja zakłada konieczność zapewnienia szczególnej opieki zdrowotnej dzieciom, kobietom ciężarnym, osobom niepełnosprawnym i w wieku podeszłym. Dodać należy, że prawo do ochrony zdrowia zostało zakwalifikowane przez ustawodawcę jako prawo socjalne, co jest przejawem szczególnej troski władz publicznych o obywateli [6]. Zakres i zasady udzielania świadczeń zdrowotnych zostały uregulowane w ustawie z dnia 27 sierpnia 2004 r. o świadczeniach opieki zdrowotnej finansowanych ze środków publicznych (dalej: u.ś.o.z.) [7]. Ustawodawca wyodrębnił dwie kategorie osób uprawnionych do korzystania z bezpłatnych świadczeń opieki zdrowotnej, tzw. świadczeniobiorców: ubezpieczonych oraz inne osoby spełniające kryteria wynikające z przepisów prawa [8].

Zamierzeniem autorki niniejszej pracy była analiza przepisów prawa stanowiących podstawę odmowy udzielenia świadczenia zdrowotnego przez lekarza oraz wiążących się z tą decyzją obowiązków. Niniejsza tematyka zasługuje na uwage głównie w kontekście wydanego w dniu 7 października 2015 r. wyroku Trybunału Konstytucyjnego uznającego częściową niekonstytucyjność art. 39 ustawy z dnia 5 grudnia 1996 r. o zawodach lekarza i lekarza dentysty (dalej: u.z.I.) [9].

\section{Prawo do świadczeń zdrowotnych}

Szczegółowo prawa pacjenta reguluje ustawa z dnia 6 listopada 2008 r. o prawach pacjenta i Rzeczniku Praw Pacjenta (dalej: u.p.p.) [10]. Rozdział 2 ustawy gwarantuje pacjentowi prawo do świadczeń zdrowotnych. $W$ ramach tego prawa ustawodawca wskazał, iż udzielane świadczenia muszą odpowiadać wymaganiom aktualnej wiedzy medycznej (art. 6 ust. 1 u.p.p.). Pojęcie to należy rozumieć jako konieczność stosowania wyłącznie obowiązujących metod leczenia. Tym samym nie należy udzielać świadczeń zdrowotnych przestarzałych czy negatywnie ocenianych przez przedstawicieli współczesnych nauk medycznych. Wyklucza się także stosowanie niezweryfikowanych naukowo metod leczenia. Wyjątkiem od tej reguły są eksperymenty medyczne, których przeprowadzenie jest możliwe po spełnieniu odpowiednich wymogów określonych w przepisach prawa [11].
W sytuacji, gdy po stronie podmiotu leczniczego wystąpią ograniczenia uniemożliwiające udzielenie koniecznych świadczeń zdrowotnych, pacjent ma prawo do umieszczenia go na tzw. liście oczekujących. Ustawodawca w art. 6 ust. 2 u.p.p. zawarł wytyczne, jakie powinny być stosowane w procedurze ustalającej kolejność dostępu do świadczeń zdrowotnych. Przede wszystkim powinna być ona przejrzysta, obiektywna i oparta na kryteriach medycznych. To ostatnie kryterium wskazuje na to, że decydujący powinien być stan zdrowia pacjenta, a nie inne względy, jak np. wiek czy status społeczny. Powyższa procedura nie ma zastosowania w przypadku, gdy zagrożone jest życie lub zdrowie pacjenta. Wówczas ma on prawo do natychmiastowego uzyskania świadczeń zdrowotnych (art. 7 ust. 1 u.p.p.). Podobnie w przypadku porodu pacjentka ma prawo do uzyskania świadczeń zdrowotnych związanych z porodem.

Ustawa o prawach pacjenta i Rzeczniku Praw Pacjenta w ramach prawa do świadczeń zdrowotnych przyznaje pacjentowi prawo żądania od lekarza udzielającego mu tych świadczeń zasięgnięcia opinii innego lekarza lub zwołania konsylium lekarskiego (art. 6 ust. 3 u.p.p.). Również lekarz w razie wątpliwości może z własnej inicjatywy skonsultować swoją opinię z innym lekarzem lub w ramach konsylium. Powyższe uprawnienia wynikają z ustawy o zawodzie lekarza (art. 37 u.z.I.) oraz Kodeksu Etyki Lekarskiej [12], który w art. 10 stwierdza, iż lekarz nie powinien wykraczać poza swoje umiejętności zawodowe przy wykonywaniu czynności diagnostycznych, zapobiegawczych, leczniczych i orzeczniczych. Jeżeli zakres tych czynności przewyższa jego umiejętności, to winien się zwrócić do bardziej kompetentnego kolegi. Nie dotyczy to jednak wypadków nagłych i ciężkich zachorowań, gdy zwłoka może zagrażać zdrowiu lub życiu chorego.

Gdy o zasięgnięcie opinii innego lekarza lub zwołania konsylium wystąpił pacjent, lekarz może odmówić wykonania tego żądania, jeśli uzna je za bezzasadne. Powinien jednak ten fakt odnotować w dokumentacji medycznej pacjenta. Podobne uprawnienie posiada pacjent w odniesieniu do pielęgniarek i położnych, od których może żądać zasięgnięcia opinii innej pielęgniarki i położnej. Tak samo jak lekarze mogą one odmówić spełnienia powyższego żądania.

Jak słusznie wskazują Dercz, Izdebski i Rek, opinia konsultanta ma jedynie charakter doradczy, co oznacza, że za całość postępowania leczniczego odpowiada lekarz prowadzący [11].

Warto również dodać, że świadczenia zdrowotne powinny być udzielane pacjentom z należytą starannością (art. 8 u.p.p.). W myśl art. 355 par. 1 Kodeksu cywilnego pojęcie to należy rozumieć jako staranność ogólnie wy- 
maganą w stosunkach danego rodzaju. Można ją wytłumaczyć pewnym modelem postępowania zarówno w aspekcie obiektywnym, jak i subiektywnym. W rozumieniu obiektywnym należyta staranność to przestrzeganie i stosowanie się do pewnych ściśle określonych reguł i zasad postępowania, które są najczęściej sformalizowane i precyzyjnie określone. Natomiast w znaczeniu subiektywnym należytą staranność trzeba rozumieć jako osobiste zaangażowanie się w wykonywanie danej czynności [13].

Jak wskazał Sąd Najwyższy w wyroku z dnia 10 lutego 2010 r., nie chodzi tu o wymaganie od lekarza staranności wyższej od przeciętnej, jak to formułuje się w niektórych wypowiedziach, lecz o wysoki poziom przeciętnej staranności każdego lekarza jako staranności zawodowej i według tej przeciętnej ocenianie konkretnego zachowania [14].

Zgodnie z art. 8 u.p.p. świadczenia zdrowotne powinny być udzielane w warunkach odpowiadających określonym wymaganiom fachowym i sanitarnym. Dokładne wytyczne w tym zakresie zawierają odrębne przepisy prawa. Nadto przy udzielaniu świadczeń osoby wykonujące zawód medyczny powinny kierować się zasadami etyki zawodowej określonymi przez właściwe samorządy.

\section{Odmowa udzielenia świadczenia zdrowotnego}

Jak wskazano wyżej, pacjent ma zagwarantowane prawo do uzyskania koniecznych świadczeń zdrowotnych. Aby dane świadczenie mogło być udzielone, musi być poprzedzone zgodą pacjenta. Ta z kolei do swojej legalności wymaga wcześniejszego poinformowania pacjenta o stanie zdrowia, rozpoznaniu, proponowanych oraz możliwych metodach diagnostycznych i leczniczych, dających się przewidzieć następstwach ich zastosowania albo zaniechania, wynikach leczenia oraz rokowaniu (art. 9 ust. 2 u.p.p.). Do przekazania informacji oraz uzyskania zgody od pacjenta na dane badanie lub inne świadczenie medyczne zobowiązany jest zgodnie a art. 32 ust. 1 ustawy z dnia 5 grudnia 1996 r. o zawodach lekarza i lekarza dentysty - lekarz. Jeżeli pacjent jest małoletni, zgodę wyraża jego przedstawiciel ustawowy, a w razie niemożności jej uzyskania - sąd opiekuńczy. Ustawodawca dopuścił jednocześnie możliwość udzielenia pacjentowi świadczenia zdrowotnego bez jego zgody w sytuacji, gdy wymaga on niezwłocznej pomocy lekarskiej, a ze względu na stan zdrowia lub wiek nie może wyrazić zgody i nie ma możliwości porozumienia się z jego przedstawicielem ustawowym lub opiekunem faktycznym (art. 33 u.z.l.). Decyzję taką lekarz powinien w miarę możliwości skonsultować z innym lekarzem oraz odnotować w dokumentacji medycznej pacjenta.
Ustawa o zawodzie lekarza daje mu również możliwość zadecydowania o niepodejmowaniu lub odstąpieniu od leczenia pacjenta z ważnych powodów, z wyjątkiem sytuacji, gdy zwłoka w udzieleniu świadczenia zdrowotnego mogłaby spowodować niebezpieczeństwo utraty życia, ciężkiego uszkodzenia ciała lub ciężkiego rozstroju zdrowia (art. 38 u.z.l.). Co więcej, lekarz może powstrzymać się od wykonania świadczeń zdrowotnych niezgodnych z jego sumieniem, z zastrzeżeniem sytuacji wskazanych powyżej (art. 39 u.z.l.). Zauważyć należy, że możliwość powstrzymania się od wykonania „świadczenia zdrowotnego" niezgodnego z sumieniem jest pojęciem szerszym niż „leczenie”.

W sytuacji odmowy wykonania świadczenia zdrowotnego lekarz powinien uzasadnić i odnotować ten fakt w dokumentacji medycznej pacjenta. Z powyższego uprawnienia może skorzystać bez względu na to, w jakiej formie prawnej wykonuje zawód. Jednak jeśli jest zatrudniony na podstawie stosunku pracy lub w ramach służby, to dodatkowym wymogiem jest konieczność uzyskania zgody przełożonego, a jeśli powołuje się na klauzulę sumienia, to wystarczy powiadomienie go na piśmie.

Artykuł 39 u.z.l. do zeszłego roku przewidywał także konieczność wskazania pacjentowi przez lekarza realnych możliwości uzyskania świadczenia, którego odmówiono u innego lekarza lub w podmiocie leczniczym. Powyższy zapis był przedmiotem rozważań Trybunału Konstytucyjnego, który w wyroku z dnia 7 października 2015 r. uznał, iż jest niezgodny z art. 53 ust. 1 w związku $z$ art. 31 ust. 3 Konstytucji i tym samym z dniem 16 października 2015 r. utracił moc obowiązującą [15]. Podobnie Trybunał Konstytucyjny orzekł w zakresie, w jakim przepis art. 39 u.z.l. nakładał na lekarza obowiązek wykonania niezgodnego z jego sumieniem świadczenia zdrowotnego nie tylko w sytuacjach, gdy zwłoka w jej udzieleniu mogłaby spowodować niebezpieczeństwo utraty życia, ciężkiego uszkodzenia ciała lub ciężkiego rozstroju zdrowia, ale także $w$,innych przypadkach niecierpiących zwłoki", uznając, iż jest on niejasny i niezgodny z zasadą prawidłowej legislacji wywodzoną z art. 2 Konstytucji Rzeczypospolitej Polskiej i art. 53 ust. $1 \mathrm{w}$ związku z art. 31 ust. 3 Konstytucji [15]. Tym samym Trybunał uznał naruszenie konstytucyjnej zasady gwarantującej każdemu wolność sumienia i religii oraz wskazał, iż „ograniczenia w zakresie korzystania z konstytucyjnych wolności i praw mogą być ustanawiane tylko w ustawie i tylko wtedy, gdy są konieczne w demokratycznym państwie dla jego bezpieczeństwa lub porządku publicznego, bądź dla ochrony środowiska, zdrowia i moralności publicznej, albo wolności i praw innych osób. Ograniczenia te nie mogą naruszać istoty wolności i praw" [16]. 
Zdaniem Trybunału nałożenie na lekarzy obowiązku udzielenia pacjentowi realnej pomocy w uzyskaniu świadczenia zdrowotnego u innego lekarza poprzez konieczność przekazania takich informacji jest naruszeniem ich wolności sumienia.

Warto zaznaczyć, że na powyższy problem w nieco innym aspekcie wskazywano już znacznie wcześniej. Jak słusznie zauważył L. Kubicki, skoro lekarz ma udzielić pacjentowi informacji, to powinien ją sprawdzić i na bieżąco weryfikować, aby nie wprowadzić pacjenta w błąd [19]. Tak więc założenie, choć słuszne w punktu widzenia praw pacjenta, to jednak w praktyce jest trudne do zrealizowania. W związku z powyższym właściwa wydaje się propozycja E. Zielińskiej, wysunięta już w 2003 roku, aby powyższy obowiązek przerzucić na podmiot leczniczy, w którym lekarz jest zatrudniony, a w przypadku lekarzy wykonujących zawód w ramach praktyki zawodowej - na terenowe oddziały Narodowego Funduszu Zdrowia lub Okręgowe Izby Lekarskie [21].

Powyższą kwestię próbowano częściowo rozwiązać rozporządzeniem Ministra Zdrowia z dnia 6 października 2005 r. w sprawie ogólnych warunków umów o udzielanie świadczeń opieki zdrowotnej [22], które nakładało na publiczny zakład opieki zdrowotnej obowiązek zagwarantowania kobiecie ciężarnej realizacji jej uprawnienia do aborcji w sytuacji, gdy pozwala na to ustawa. Była to reakcja Ministra Zdrowia na pojawiającą się w szpitalach praktykę wywieszania ogłoszeń informujących, że w danej placówce zabiegów przerywania ciąży się nie wykonuje. Niniejszą regulację argumentowano faktem, iż klauzula sumienia może dotyczyć lekarzy, a nie publicznych zakładów, które muszą zapewnić realizację praw pacjenta [23]. W kolejnym jednak rozporządzeniu Ministra Zdrowia z dnia 6 maja 2008 r. w sprawie ogólnych warunków umów o udzielenie świadczeń opieki zdrowotnej [24] obowiązek ten nie został już zawarty [23].

Wskazana wyżej propozycja przerzucenia obowiązku informacyjnego na podmiot leczniczy nie znalazła do tej pory odzwierciedlenia w przepisach prawa. Jednak wyrok Trybunału Konstytucyjnego z dnia 7 października 2015 r. spowodował konieczność wprowadzenia odpowiednich zmian. Obecnie bowiem istnieje luka polegająca na tym, że pacjent, któremu lekarz odmówi świadczenia niezgodnego z sumieniem, nie ma w ogóle zagwarantowanych możliwości otrzymania informacji o placówkach lub lekarzach, którzy podejmą się wykonania takiego świadczenia. Na powyższy problem zwraca uwage m.in. Rzecznik Praw Obywatelskich oraz prezes NFZ, który o korektę przepisów wystąpił już do resortu zdrowia [17]. Jak podaje „Rzeczpospolita” wbrew pozorom powstała sytuacja może okazać się trudna i kosztowna. Powinien bowiem istnieć od- powiedni rejestr. $\mathrm{Na}$ jego stworzenie, prowadzenie i uzupełnianie trzeba znaleźć pieniądze. Nie jest też do końca znana reakcja samych lekarzy, którzy mogą nie życzyć sobie podawania takiego katalogu do wiedzy publicznej, bo mogłoby to być postrzegane jako równoznaczne z upowszechnianiem wiadomości na temat ich osobistych postaw religijnych czy politycznych [18].

$\mathrm{Na}$ inny problem wskazuje Małgorzata Szeroczyńska w glosie do ww. wyroku Trybunału. Zdaniem autorki powołanie się przez lekarza na klauzulę sumienia może prowadzić do sytuacji nierównego traktowania pacjenta ze względu na ściśle indywidualne przekonania moralne lekarza odmawiającego wykonania świadczenia zdrowotnego, którego by nie doznał w tej samej sytuacji inny pacjent korzystający z usług innego lekarza. Niezmiernie istotne w ocenie usprawiedliwienia istnienia takiego nierównego traktowania jest, czy pacjent uprzednio wiedział o tym, jakie są poglądy lekarza i czy z klauzuli sumienia skorzysta (można w tym przypadku założyć odpowiedź negatywną, bo gdyby pacjent wiedział o poglądach lekarza, to nie zwróciłby się do niego o pomoc, aby się nie narazić na odmowę świadczenia ze względu na klauzulę sumienia). Tak więc Trybunał Konstytucyjny powinien skonfrontować prawo do odmowy zachowania sprzecznego z sumieniem z zasadą równości oraz zasadą niedyskryminacji, a tego nie zrobił - na co wskazał sędzia Andrzej Wróbel w zdaniu odrębnym [17].

Zagadnienie klauzuli sumienia należy rozpatrywać nie tylko na gruncie prawnym, ale również etycznym. Do kwestii tej w kilku miejscach odnosi się Kodeks Etyki Lekarskiej. Już w art. 1 ust. 2 KEL podkreśla, że zasady etyki lekarskiej wywodzące się z ogólnych norm etycznych zobowiązują lekarza do przestrzegania praw człowieka i dbania o godność zawodu lekarskiego, co zdaniem L. Kubickiego należy rozumieć jako niedopuszczalność powołania się na klauzulę sumienia w celu np. dyskryminacji danej grupy pacjentów ze względu na narodowość, rasę, religię, przekonania polityczne itp. [19]. Jak słusznie wskazuje Świderska, konflikt sumienia może dotyczyć jedynie istoty świadczenia zdrowotnego, a nie osoby pacjenta. Wynika to wprost z konieczności poszanowania praw jednostki bez względu na osobiste uprzedzenia lekarza. Jak wskazała autorka już w 2007 roku - w związku w powyższą argumentacją celowe byłoby utworzenie rejestru oświadczeń lekarzy, z którego wynikałoby, jakiego rodzaju świadczeń zdrowotnych się nie podejmują. Powyższe rozwiązanie nie ma jednak podstawy prawnej [20]. Należy dodać, że w świetle przytoczonego wyżej orzeczenia Trybunału Konstytucyjnego konieczne stało się znalezienie właściwego rozwiązania powyższej kwestii.

Do klauzuli sumienia odnosi się również art. $4 \mathrm{KEL}$, który zakłada, że lekarz, aby wypełniać swoje zadania, 
powinien zachować swobodę działań zawodowych, zgodnie ze swoim sumieniem i współczesną wiedzą medyczną. Natomiast art. $7 \mathrm{KEL}$ (podobnie jak art. 38 u.z.l.) przyznaje lekarzowi możliwość niepodejmowania lub odstąpienia od leczenia chorego w szczególnie uzasadnionych wypadkach. Wyjątek stanowią jedynie przypadki niecierpiące zwłoki. Nie podejmując albo odstępując od leczenia, lekarz winien jednak wskazać choremu inną możliwość uzyskania pomocy lekarskiej.

\section{Zakończenie}

Przepisy prawa powinny chronić zarówno pacjentów, jak i lekarzy. Choć ustawodawstwo polskie gwarantuje pacjentom prawo do uzyskiwania odpowiednich świadczeń zdrowotnych, to w praktyce nie zawsze jest to możliwe. Lekarz może bowiem odmówić ich udzielenia, jeśli są one niezgodne z jego sumieniem. W odniesieniu do klauzuli sumienia można wskazać zarówno zalety, jak i wady. Gwarantuje ona lekarzom wolność sumienia, postępowanie zgodne ze swoimi przekonaniami oraz chroni przed przymusem naruszania własnych zasad etycznych. Z drugiej jednak strony może ograniczać pacjentom dostęp do świadczeń zdrowotnych. Dlatego też konieczna jest taka zmiana przepisów prawa, która zminimalizuje powyższe ryzyko poprzez zagwarantowanie dostępu do informacji o możliwości uzyskania danego świadczenia w innej placówce ochrony zdrowia.

\section{Piśmiennictwo}

1. Karta Narodów Zjednoczonych, http://libr.sejm.gov.pl/tek01/ txt/onz/1945.html (data dostępu: 25.04.2016).

2. Powszechna Deklaracja Praw Człowieka, http://www.unesco.pl/fileadmin/user_upload/pdf/Powszechna_Deklaracja_Praw_Czlowieka.pdf (data dostępu: 25.04.2016).

3. Międzynarodowy Pakt Praw Ekonomicznych, Socjalnych i Kulturalnych, Dz.U. 1977, nr 38 poz. 169.

4. Konstytucja Światowej Organizacji Zdrowia, Nowy Jork dnia 22 lipca 1946 r., Dz. U. 1948 nr 61, poz. 477 z późn. zm.

5. Ustawa z dnia 2 kwietnia 1997 r. Konstytucja Rzeczypospolitej Polskiej, Dz.U. Nr 78, poz. 483 z późn. zm.

6. Surówka A. Miejsce konstytucyjnego prawa do ochrony zdrowia w systemie praw i wolności człowieka i obywatela. Prz Prawa Konstytucyjnego 2012; 3: 97.

7. Ustawa z dnia 27 sierpnia 2004 r. o świadczeniach opieki zdrowotnej finansowanych ze środków publicznych, Dz. U. z 2008 r. Nr 164, poz. 1027 z późn. zm.

8. Nowak-Kubiak J, Łukasik B. Ustawa o świadczeniach opieki zdrowotnej finansowanych ze środków publicznych. Komentarz. Warszawa: Wolters Kluwer; 2010. 16.

9. Ustawa z dnia 5 grudnia 1996 r. o zawodach lekarza i lekarza dentysty, Dz. U. 2015 poz. 65.
10. Ustawa z dnia 6 listopada 2008 r. o prawach pacjenta i Rzeczniku Praw Pacjenta, Dz.U. 2009 nr 52 poz. 417 z późn. zm.

11. Dercz M, Izdebski H, Rek T. Dziecko - pacjent i świadczeniobiorca. Warszawa: Wolters Kluwer; 2015. 104-112.

12. Kodeks Etyki lekarskiej http://www.nil.org.pl/_data/assets/ pdf_file/0003/4764/Kodeks-Etyki-Lekarskiej.pdf (data dostępu: 25.04.2016).

13. Patyn R. Określenie zasady postępowania lekarza z należytą starannością z płaszczyzny orzecznictwa sądowego, Prawo i Medycyna 2012; 2.

14. Wyrok Sądu Najwyższego z dnia 10 lutego 2010 r., VCSK 287/09.

15. Wyrok Trybunału Konstytucyjnego z dnia z dnia 7 października 2015 r., sygn. akt K 12/14, Dz.U. poz. 1633.

16. Konstytucja RP z dnia 2 kwietnia 1997 r., Dz.U. 1997 nr 78 poz. 483.

17. Szeroczyńska M. Glosa do wyroku Trybunału Konstytucyjnego z dnia 7 października 2015 r. (sygn. K 12/14). Klauzula sumienia lekarzy, http://www.prawaczlowieka.edu.pl/index.php?orzeczenie=7c9fe6831f52e30e0ede4f8c54fd9bba673e8d8b-b0 (data dostępu: 3.05.2016).

18. Przepisy o klauzuli sumienia do wymiany lub uzupełnienia, Rzeczpospolita z dnia 6.04.2016 r.

19. Kubicki L. Sumienie lekarza jako kategoria prawna. Prawo i Medycyna 1999; 4: 8.

20. Świderska M. Zgoda pacjenta na zabieg medyczny, Toruń: Dom Organizatora; 2007. 196.

21. Zielińska E. Klauzula sumienia, Prawo i Medycyna 2003; 13: 30.

22. Rozporządzenie Ministra Zdrowia z dnia 6 października 2005 r. w sprawie ogólnych warunków umów o udzielanie świadczeń opieki zdrowotnej, Dz. U. Nr 197, poz. 1643 załącznik - ogólne warunki - par. 8 ust. 3.

23. Nesterowicz M, Karczewska N. Stosowanie klauzuli sumienia, http://www.ptb.org.pl/pdf/nesterowicz_karczewska_klauzula_1.pdf (data dostępu: 13.10.2016).

24. Rozporządzenie Ministra Zdrowia z dnia 6 maja 2008 r. w sprawie ogólnych warunków umów o udzielenie świadczeń opieki zdrowotnej, Dz. U. Nr 81, poz. 484.

Artykuł przyjęty do redakcji: 03.06.2016

Artykuł przyjęty do publikacji: 21.10.2016

Źródło finansowania: Praca nie jest finansowana z żadnego źródła. Konflikt interesów: Autorzy deklarują brak konfliktu interesów.

\author{
Adres do korespondencji: \\ Joanna Zdanowska \\ ul. Mariana Smoluchowskiego 11 \\ 60-179 Poznań \\ tel.: 618612250 \\ e-mail: jzdano@ump.edu.pl \\ Zakład Organizacji i Zarządzania w Opiece Zdrowotnej, \\ Uniwersytet Medyczny im. Karola Marcinkowskiego w Poznaniu
}

